\title{
Innovation Patterns in the Canned Fish Industry in Galicia (Spain)
}

\section{Manuel González-López ${ }^{1}$}

\begin{abstract}
In this paper, we analyze the competitive and innovative trajectories followed by the canned fish industry in recent times. We base our study on four case studies from the Galician industry in Spain, which comprises the largest share of the European canned fish sector. At least four different innovation patterns are found in the industry. The first pattern is a conservative one where innovation is seen as a risk and therefore maintaining current routines is the chosen option. The second pattern has been defined as "large retailer-dominated" and is followed by companies that have signed exclusive agreements with large retailers, which increasingly determine most of their innovation activities. The third strategy we have defined as "territory-orientated," since product innovation and incorporation of quality distinctions based on the territory are the main innovation drivers. Finally, we have an "ecological or natureorientated" innovation strategy where meeting ecological normative requirements is the main innovation driver.
\end{abstract}

Keywords: canned fish, innovation, trajectories, food industry, value chain, retailers, private labels, territory, ecological products.

\section{INTRODUCTION}

The canned fish industry is one of the first examples of how modern industry entered into food production, as factory processing in this sector had already started by the middle of the 19th century. As with many other traditional industries in Europe, the canned fish industry has been affected by delocalization processes during the last decades. Nevertheless, in some European regions, it still has a strong presence in the economy and is also one of the few industries performing reasonably well in the current economic crisis. This is the case in Galicia, in North-West Spain, where less than 70

1 Manuel González-López, Ph.D., Department of Applied Economics, ICEDE Research Group, University of Santiago de Compostela, Rectorado, Praza do Obradoiro, s/n, 15782 Santiago de Compostela, La Coruña, Spain, e-mail: Manuel. gonzalez.lopez@usc.es. 
companies produce around $85 \%$ of the total Spanish canned fish products and, with regards to canned tuna, 50\% of total European production (ANFACO, 2013). Despite these figures, however, the sector has suffered a deep restructuring process during the last decades as the number of companies declined abruptly and many of the surviving firms changed their competitive strategy (Carmona \& Fernández, 2001). Since the 1990s, the sector has shown a strong concentration of production and a marked heterogeneous internal composition. On the one hand, there is a small of group of large companies which started an internationalization strategy, both in terms of trade and capital, some of which have become major multinational companies at a world level. Together with this small group of companies, the second group of SMEs has survived following different strategies. Some of them relied upon differentiation, focusing on artisanal processing and seasonal local species while others tried to survive by means of collaboration with larger companies or conserving their traditional client networks.

This paper aims to discuss the competitive and innovative trajectories followed by the canned fish industry during recent years based on the case of Galicia. In particular, we try to answer the question of why canned fish producers have followed different evolutionary paths and how they have managed, from an innovation strategy viewpoint, to follow such diverse trajectories. In the next section, we will discuss the relevant literature concerning innovation and change in the food industry, with a particular focus on contributions made by the Evolutionary School and the Relational Economic Geography stream. Later on, we present the main results of our empirical analysis, in which the cases of four representative companies have been studied in depth. Finally, some conclusions are drawn and summarized in the end section of the paper.

\section{LITERATURE REVIEW}

Change and innovation in the food industry: strategies of the embedded firm The evolutionary theory of firms: routines and changes

Nelson and Winter (1982) established the foundations of the Evolutionary theory of the firm in their book 'An Evolutionary Theory of Economic Change.' The evolutionary theory of the firm rests on the idea that companies cannot be considered as homogeneous units since they differ from one another in terms of their internal organizations, knowledge bases, capabilities and also in terms of their respective strategies for confronting change.

A major concept of the evolutionary theory of firms refers to routines. Routines and habits explain a good deal of the behavior of firms since 
they facilitate decision-making, create stability and make the exchange of knowledge and information easier. As pointed out by (Nelson, 1994) a firm can be understood in terms of a hierarchy of practiced organization routines. Cohen et al. (1996, p. 683) define routines as "an executable capability for repeated performance in some context that has been learned by an organization in response to selection pressure." Firms' routines are nevertheless subject to continuous changes due to internal and external forces. Breaking and changing routines can, in the final analysis, be associated with the process of innovation itself, understood in Schumpeterian terms as new combinations of production factors.

Therefore firms usually rely upon routines that give them a basis of stability - but, at the same time, firms do change their routines when they innovate. This leads us to a second major concept of the evolutionary theory of the firm, which is "path-dependency." Firms evolve following a path determined by past routines, practices and knowledge that need to be adapted to new contexts and realities. Consequently, history matters and companies' decisions are taken according to an established trajectory of knowledge accumulation, past decisions, etc... The direction of those changes and trajectories is not easily predictable because uncertainty, rather than perfect information, dominates the scene (Dosi, 1988). The former constitutes a major difference between the evolutionary and the neoclassical schools of economic thought. In fact, "bounded rationality" can be considered as another central concept for evolutionary advocates since they understand that economic actors cannot know exactly what the outcomes of their actions will be. Therefore there are hardly any optimal choices and efficient outcomes in the evolutionary paradigm, but rather trajectories shaped by incomplete information, past decisions and present circumstances.

Moreover, firms differ in their innovation strategies to confront market changes (Schamp, 2005). A large literature exists concerning the different innovative strategies of firms at both an individual and aggregate level. As pointed out by Freeman (1982), whilst some companies follow traditional, dependent or imitative strategies and hardly get involved in R\&D activities (apart from adaptive R\&D), others exhibit more proactive behavior where innovation is concerned (defensive or offensive strategies). At sector level, the well-known taxonomy established by (Pavitt, 1984) identifies different sectoral patterns of innovation. While some companies, like the ones belonging to primary or traditional industries, are characterized as "supplier dominated" from a technological viewpoint, others are more prone to carry out their own innovative activities ("science-based" sectors or "specialized suppliers" sectors). We could, therefore, say that the response to technological change varies according to the type of firm and sector. 
Finally, every firm has its own knowledge base that Nelson and Winter (1982) refer to as "production knowledge." The authors put a particular emphasis on tacit knowledge, capabilities and know-how stored in firms in the form of routines. Some firms possess a strong scientific knowledge base, such as those belonging to research-intensive sectors such as pharmaceuticals or chemicals, and all firms also have a basis of tacit knowledge, which can be understood as knowledge that cannot be easily codified or standardized.

The importance given to implicit or tacit knowledge links the evolutionary theory of the firm with another important theoretical framework. Tacit knowledge is usually context-specific knowledge and hence is embedded in particular geographical, cultural and institutional contexts (Grabher, 1993). This consideration narrowly links the evolutionary school of economic thought with some contemporary contributions from the discipline of economic geography, sometimes labeled as relational economic geography. ${ }^{2}$ Hayter \& Patchell (2011), following previous contributions made by Storper (1997), indicate that the spatial distribution of economic activities must be understood within a framework of interaction between institutions, markets and technology that takes place in time and space. The context within which that interaction occurs is characterized by three principles that are easily connected to evolutionary economics: embeddedness, differentiation and evolution. Embeddedness refers to the inseparability of economic and non-economic factors where production activities are concerned. Evolution implies that market processes are fundamentally transformative, and that market economies change over time with respect to the location, nature, and organization of economic activities. Finally, differentiation refers to the unique nature of the places and spaces where interaction between markets, institutions and technology takes place (Hayter \& Patchell, 2011, p. xvi). As we will see in the next section, changes in the food industry have already been analyzed from this perspective by different authors.

\section{Changes in the food value chain: nature, territory and quality}

According to Malassis (1977), two main processes have determined food production in contemporary times, the first being the growing industrialization of the agro-food chain and the second one the growing level of capitalization, concentration and internationalization. Industrialization has meant a structural transformation of the food sector manifested in a relative decline of the value added by agrarian activities (and a correlative increase of the value added in other stages like processing, distribution, etc.). Besides this, such industrialization processes have been associated with a generalization of industrial processes along the value chain. Regarding the second process, Malassis indicated that

2 For a review see Martin (1999) or Scott (1988). 
the introduction of capitalist forms into the agro-food sector has led to the emergence of giant industrial groups, operating on an international scale, in both the processing and distribution spheres. In this sense, according to the author, the agro-food market is a good example of an oligopolistic market based on monopolistic competence among a few stakeholders.

The changes pointed out by Malassis at the end of the 1970s have probably deepened further during the last two decades, in particular, due to the acceleration of the globalization process which has occurred since that time. Thus, the new agro-food chain described by Malassis 40 years ago is usually referred to nowadays as the "conventional mode of agriculture development and food production" (Morgan \& Murdoch, 2000). The oligopolistic character of the food sector is manifested now as the dominance of (a few) giant distributors and retailers that act as "price-makers" while a large number of farmers and primary producers have become "price-takers" (Morgan, Marsden \& Murdoch, 2008). Even the large processors which emerged during the 20th century have had to readjust to the hegemonic role now played by large-scale retail (Wilkinson, 2002). This last author points out that two major factors have affected the food value chain in the last decades: on the one hand, there has been an emergence of functional foods lead by science-based companies and on the other, as a response to the previous trend, there has been an explosion of organic food in food markets lead by large-scale retailers. As a result food producers now occupy a narrower space, particularly in terms of innovation, along with the food value chain. In the same vein, Burch and Lawrence (2005) consider that the effect of the dominance of large retailers that sell their own brand products is the creation of a "third food regime" where food firms act merely as flexible manufacturers attending retailers' desires to attend highlysegmented niche markets. As pointed out by the authors "There seems to us to be clear evidence that a retailer-dominated food production system has a different profile and trajectory from the two earlier regimes where power rested first, with the settler capitalist state/farm lobby and, second with the mass producers of branded food products" (Burch \& Lawrence, 2005, p. 14).

From a different perspective (Morgan \& Murdoch, 2000) have discussed the role of knowledge production and distribution to explain the diversity of food supply chains. In particular, they discuss the differences between two food chains: the conventional agri-food chain and the organic agri-food supply chain, and they argue that the way knowledge is distributed along the chain varies from one to the other and, to some extent, the knowledge type is also different in each case. According to the authors, the emergence of the conventional chain meant that farmers' local (traditional) knowledge was displaced by standardized knowledge coming from supply industries (such as growing mechanization, use of chemicals as fertilizers, etc.). The authors also 
implied a net loss of power in the production chain by farmers in such a way that they have become the weakest link in the food chain. In the organic food chain a different set of practices and knowledge are needed to those of the conventional system and, to some extent, farmers recover old forms of local/ traditional knowledge which is much more in tune with the maintenance of ecosystems. As indicated by the authors, in the organic chain, farmers can once again become "knowing agents."

Finally, the changes which have happened in the food value chain have also had consequences on the geography of the agro-food production system. One of these major consequences is the "deterritorialization" of the food system due to the growing control of firms working on an international scale and therefore imposing a global logic into the system (Morgan et al., 2008). Nevertheless, the aforementioned general trends do not mean that alternative paradigms or trajectories do not exist or have not emerged during all this time. As also pointed out by Morgan et al. (2008), the globalization process followed by the food sector is constrained by two factors that determine the geography of food since they are territorially fixed: these factors are "nature" and "culture." With regard to nature, although some natural constraints of food production, namely seasonality, have been overcome by industrialization forces (new conservation methods and growing technologies) and globalization forces (decreasing the cost of transport, trade liberalisation, etc.), this has not substituted the "old" role of nature and a growing trend associating food quality with non-industrialized practices has emerged. Something similar happens in terms of culture, since local cultures of production and consumption have been re-evaluated during recent years as a counterforce against standardization of products and tastes. The appearance of "guarantee of origin" denominations and others are a potential example of this. Therefore, where changes in the geography of food systems are concerned, a dialectical process between "deterritorialization" and "territorialization" forces has taken place.

Therefore, despite the dominance of the conventional model, there is not only one paradigm explaining the configuration of the food industry but diverse patterns that vary according to the interaction between institutions, territories and technologies.

We will see in the following paragraphs how all these factors affecting the food system as a whole are highly present in the case of the canned food industry and how therefore they help us to understand the changes which have happened in the sector during the last decades. The following paragraphs will be devoted to giving an overview of the Galician canned fish industry and detailing the results of the cases analyzed during our research. 


\section{STUDY}

\section{The canned fish industry confronting global and institutional changes} The Galician canned fish sector: a brief view of its history and current figures The canned fish industry is the most representative sector of the modest industrialization process which took place in Galicia between the end of the 19th century and the beginning of the 20th century. Its roots can be found in the traditional salted fish plants, which were historically situated in sea towns. The first Galician canned fish companies were established in the first half of the 19th century although their growth was not significant until the end of that century. Thanks to nearby natural resources, the improvement of the communication infrastructure in Spain and favorable trade policies as well as the spread of French technology, the sector developed quickly and became one of the main exporter industries in Spain during the first quarter of the 20th century (Carmona, 1994).

The Spanish civil war marked an inflection point for the industry as, once it ended, the strong trade protection offered by the fascist regime allowed non efficient companies to maintain their activity artificially since it was an administrative decision (public quotes) and not a market decision which determined their success. Meanwhile, in other countries, the sector experienced quick growth due to strong investments and technological advances that made the Galician and Spanish sectors lag behind, by international standards. This is the main reason why the sector suffered a deep restructuring process once the Spanish economy opened to international competition at the beginning of the 1960s. The number of companies declined dramatically from 160 in 1965 to 80 in 1985 (Carmona \& Fernandez, 2001). Most companies simply closed down or were acquired by bigger companies.

According to data provided by the National Association of Canned Fish Producers (ANFACO, 2013), in 2012 the Galician canned fish industry consisted of 65 companies that employed 11,950 people. That year, the industry processed more than 300,000 tonnes of fish, reaching an economic value of 1.25 billion Euros, which represented $84.4 \%$ of Spanish fish production. More than $40 \%$ of this production was exported, mostly to other European countries. Tuna is the most significant processed product, constituting around $64 \%$ of the total volume of products processed and $50 \%$ of the industry turnover in 2010. The second most significant product is sardines, although far less significant than tuna, constituting around $7.8 \%$ of the total volume processed and $6.4 \%$ in economic terms. Other important species are mussels ( $4.1 \%$ of total volume and $7.5 \%$ of total value) and cockles ( $1.4 \%$ of total volume and $5.9 \%$ of total value). As can be observed in the previous figures, shellfish species like mussels and cockles, which are typical species 
of the Galician "rias" (estuaries) and are historically rooted in the region's traditional cuisine, usually represent a higher value added than other species.

Data provided by ARDAN (2011), a statistical data provider specializing in firm structure and finance, allows us to see the industry's internal structure. Through this data, we can see that the industry was dominated by SMEs at the end of the last decade as they represented $71 \%$ of all companies ( 38 firms having a turnover between 2 and 60 million Euros). Only five companies could be considered large companies, understood here as those exceeding a turnover of 60 million Euros. Finally, a small group of 10 micro-companies registered a turnover lower than 2 million Euros. Nevertheless, when it comes to the economic weight of each type of company, we can easily see the dominance of large companies. Thus, the five largest companies registered $63.8 \%$ of the total turnover in the Galician canned fish industry, 35.3\% is the figure for SMEs and just $0.9 \%$ for micro-firms. The sector's production is therefore strongly concentrated in a small number of companies, most of them already multinational firms with a presence in other countries of the world.

Table 1. The Galician canned fish sector: internal configuration

\begin{tabular}{llll}
\hline & Number & \% Companies & \% Turnover \\
\hline Large & 5 & 9.4 & 63.8 \\
Medium & 14 & 26.4 & 27.8 \\
Small & 24 & 45.3 & 7.5 \\
Micro & 10 & 18.9 & 0.9 \\
\hline
\end{tabular}

Source: own elaboration based on data provided by ARDAN (2011) and companies reaching a turnover of 1 million Euros

\section{THE FIELD RESEARCH}

\section{Four cases and four strategies to survive}

We have carried out field research in order to understand the changes affecting the Galician canned fish industry during recent years as well as the diverse strategies followed by the sector's firms. In particular, we focus on four companies that were previously selected on the basis that they represent different paradigms within the sector. Such pre-selection was established partially following the insights pointed out by Carmona and Fernandez (2001) as detailed above, also based on the information obtained from different sources which we refer to in the following paragraphs.

The research was conducted as follows: we first compiled information on the industry, making particular use of Industria Conservera, the periodical journal published by the National Association of Canned Fish Producers 
(ANFACO). We then contacted the technological center of this association (ANFACO-Cecopesca) - which was created in 1949 and is one of the oldest technological centers in Spain - where we interviewed the responsible person at the Department of Technology Transfer. During the interview, we not only approached technological and innovative aspects but also broader aspects related to the industry's evolution during recent decades as well as its current structure.

Based on the information obtained from publications and during this first interview, we identified four types of companies that, overall, are representative of the different strategies followed by this industry. The next paragraphs will be devoted to the description of each of these companies which, as the final stage of our field research, were interviewed in depth. The interviews were semistructured since we used a questionnaire to specifically address aspects related to the competitive and innovation strategies of each firm.

\section{Company A. Traditional firm}

The first company is a medium-size firm that has employed an annual average of 40 people over the last three years and registered a turnover close to 7 million Euros in 2010. Company sales are focussed solely on the Spanish market. The firm was created at the end of the 1960s based on a family tradition of mussel farming; for this reason, they began canning mussels alone, but within a short space of time they began processing other shellfish species such as cockles and clams. Nowadays they process a wide range of products aside from shellfish, and tuna has become their main product ( $50 \%$ of sales). The competitive strategy of Firm A has not suffered significant changes during recent years. They buy their raw fish at local fish markets (shellfish species) and from large fishing fleets (tuna), some of them belonging to other, larger canned fish companies. They sell their products mainly to commercial agents (intermediaries) which supply small and traditional shops and supermarkets. They do not compete on price and their product quality can be considered medium range since their end client is the average consumer.

\section{Company B. Large multinational firm}

The second company is a large multinational firm that employs more than 500 people in Galicia and reached an average turnover higher than $\mathbf{3 0 0}$ million Euros over the last three years. The company was created in the mid-1960s and, after an ambitious and successful process of horizontal and vertical integration consolidated during the 1990s, is now one of the world's largest companies in this sector. The provision of raw material is a critical issue for the company and in order to guarantee such provision they have followed two separate strategies. On the one hand, they are involved in fishing 
activities by means of participation as shareholders in one of the largest Spanish tuna fishing fleets. On the other, they have established subsidiaries in many different countries (from South-America, Africa and Europe) where they carry out primary processing activities. From the market perspective, they also have a significant international presence that has been achieved by different means such as takeovers or joint ventures with local producers and retailers. Nevertheless, despite its considerable level of internationalization they still sell around $75 \%$ of their products within the Spanish market. This is largely due to the competitive strategy followed by this firm, which at the moment is strongly sustained by their agreement with one of the largest Spanish retailer brands, for whom they are sole producers of store brand products (representing about $65 \%$ of their sales). Although their strategy is determined by the aforementioned agreement, the group maintains several own brands, some of them in alliance with other companies, in order to attend to specific markets. Finally, the firm has recently diversified their production, entering into the ready-made food market (salads, soups, etc.) and also the pet food market, by means of exploiting by-products.

\section{Company C. Delicatessen firm}

Company $\mathrm{C}$ is a small firm that employs less than 20 people and has a turnover close to 2 million Euros. Although the firm was created at the end of the 1980s, the founders come from an old canned-industry family that was already involved in this business at the beginning of the 20th century. The founders envisioned a business concept which was different from the standard one at that time in this sector, focusing on a high-end and well-differentiated market segment. Their clients fall into two basic categories: specialized chains of high-standard products (delicatessens and gourmet shops) and restaurants. Despite their small size, their market is equally divided between Spain and other European countries (including Russia). Their competitive strategy is strongly based on product quality and in this sense they benefit from and promote the use of local fish and shellfish which is bought only during the specific biological seasons.

\section{Company D. Ecological firm}

Company $D$ is a small firm that employs less than 35 people with an average annual turnover of between 2 and 3 million euros over the last three years. It is a family-run company with a well-established presence in the sector (since the end of 19th century). At the end of the 1970s the company was set to take part in the sector's "boom" period, but due to unexpected family events their plans were thwarted. The firm continued its production without significant changes up until the beginning of the year 2000. At that moment, the owners 
decided to abandon the competitive strategy based on prices and sales to large distributors and radically changed it, opting for ecological production. They still maintain a complementary line of conventional canned fish in order to serve their traditional clients in Spain. Nevertheless ecological canned fish - which is sold mainly in the German market - is becoming their main product.

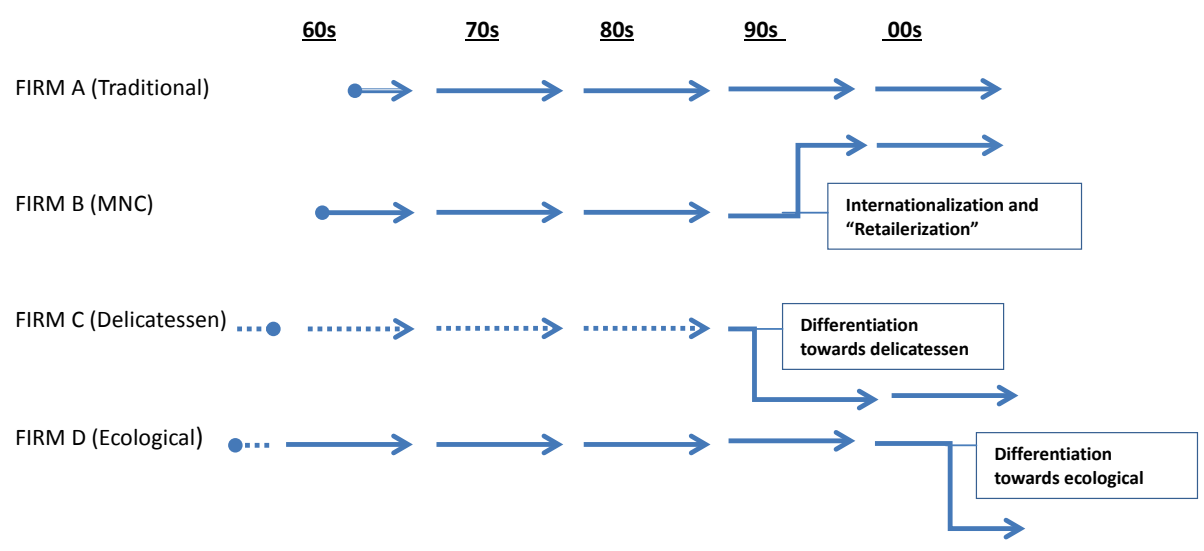

Figure 1.The firms' competitive time-trajectories

Source: our own elaboration based on the information obtained in the field research.

\section{DISCUSSION}

\section{Explaining the firms' competitive-trajectories}

The changes affecting the food system as a whole, in the direction that has already been discussed in section 2 of this paper, explain the structural change suffered by the Galician canned food industry during the last two decades quite well. In particular, the evolution of this industry is clearly determined by the consolidation of the conventional mode of food production where local/ national value chains are substituted by global ones and where large retailers exert a strong influence (Wilkinson, 2002; Morgan et al., 2008). As we will argue, this general trend has determined, in one way or another, the strategy of the four companies analyzed in our study.

In the 1990s the multinational firm aimed at following the dominant paradigm in such a way that it initiated a strong expansion of its production scale and an internationalization process to guarantee cheap raw fish and cheap processing as well as new market opportunities. Besides this, the company has sustained such expansion on the exclusive agreement it has with a large Spanish retailer. This agreement is a guarantee of being able 
to sell large volumes of produce, but it gives rise to a dependent position which the company faces in relation to the retailer. For example, though the company maintains its own brand, they have strong limitations against selling it in the Spanish market and, as indicated by the person interviewed, "foreign markets are the ones where the company is able to grow with our own brands since growing opportunities in the Spanish market are very limited due to the exclusivity agreement with the retailer". This is a clear example of how a few large retailers and distributors currently dominate the food value chain.

The other three companies were also affected by the aforementioned factors but they chose an alternative strategy to survive, an alternative paradigm of food production. In the case of the conservative firm, the strategy consisted of not varying their traditional strategy, which is based on their lifelong clients and providers and therefore they have resisted adapting to the conventional paradigm. The person we interviewed from this company was very clear about this point when, in arguing why they have avoided market agreements with large distributors and retailers, they pointed out: "they pay you badly, they squeeze you and they abandon you as soon as they have a chance." On the other hand, firms C and D were, in one way or another, forced to change their old competitive strategies as they respectively specialized on delicatessen and ecological products. As pointed out by the owner of company $\mathrm{D}$, "we changed our strategy since the small and medium-size firms of the sector will eventually have to choose between two ways: either they change their productive paradigm towards a welldifferentiated market segment or they will get absorbed by large companies, which control the provision of raw fish". Moreover, nature and territory are narrowly linked to the competitive strategy of these two firms. In the case of the ecological firm, the nature connection is not only a market device but a production requirement, while in the delicatessen firm case the connection with the territory and with the regional culture is made explicit in their marketing strategy as a signal of quality and differentiation. As a final remark regarding this strategy, we must refer to the existing trade-off between quality and quantity when dealing with different production paradigms. Thus, the company adopting the ecological strategy argued that this meant a sharp decline in production, as they had an over-capacity of production for the new market.

Therefore we can affirm that the changes in the canned food industry, as indicated by the different strategies followed by the firms within it, have been a response to the general trends affecting the food production system. Such changes have led to a global value chain consolidation dominated by large retailers and, as a response to it, to the emergence of an alternative (and diverse) paradigm where food production is based on a narrow 
connection between quality and territory. Nevertheless, as pointed out by the Evolutionary School, such a process of adaptation and change has also required changes in the way in which firms innovate and incorporate new knowledge. This issue will be discussed in more detail in the next section.

\section{Innovation patterns followed by each firm}

The firms were also questioned in depth about their innovation strategies. In particular, we asked about three different aspects of innovation. Firstly, about the kind of innovation, they have introduced during the last five years (process, product, market, and organization). Secondly, we asked about the channels of acquiring new knowledge for innovation. Finally, we also enquired about the general reasons or factors explaining the innovation strategy of each firm. In table 2 readers can find a summary of the main results. Of course, we are aware that not all innovations have the same scope. Thus, some of them refer to just incremental innovations or improvements (e.g., changes in the cans opening system) while others have a deeper impact on both firms and markets (e.g., adapting all the production chain to ecological production standards).

\section{Company A. Traditional firm: a conservative (non-innovative) strategy}

Firm A, the traditional firm, is not particularly active in terms of innovation in general. They changed the entire plant at the beginning of the 1990s and since that time they have only implemented small improvements in their processing technologies, sometimes just to meet public regulation requirements. In the remaining areas (product, organisation and market), as well as in their general attitude towards innovation, they have been quite conservative and even when explaining why significant changes have not been introduced they indicate that "the personnel does not like to change their routines, when you want to do it you have problems". As the evolutionary theory of the firm indicates, a company's nature is largely based on routines and, as we can observe, sometimes they are difficult to change as they act as barriers impeding innovation. With regards to their sources of innovation, the company points to the purchase of equipment by their providers as the main channel. They do not give too much importance to contact with clients or other firms from the same industry. Finally, they do not undertake any active $R \& D$ projects ( $R \& D$ expenditure, $R \& D$ collaboration, etc.) in line with their poor commitment to innovation. Therefore, this firm can be defined as very conservative regarding innovation and, following the traditional Pavitt's taxonomy, are essentially dependent on providers for innovation. 
Company B. Large multinational firm: innovation dominated by large retailers

As expected, the large multinational company (Firm B) shows a very different innovative profile in comparison with the traditional firm. With regards to the different areas of innovation the company is quite active in all of them, particularly in the area of process innovation since every little improvement, when large volumes are being processed, means important economic gains. The firm possesses a highly technologically advanced plant that is continuously subject to efficiency improvements. Moreover, at the moment they have an ambitious R\&D project focussed on the use of by-products which consequently implies processing innovations. Regarding product innovation, they are paying special attention towards developing products "ready to eat, ready to cook," in order to match new social demands. Another important avenue for product innovation concerns the healthy characteristics of the product (functional foods). Finally, diversifying production towards alreadymade food, based not only on fish but vegetables, is another direction the company is working on. With regards to market-related innovations, they have been particularly successful in developing new cans with easy-open systems. In terms of organization-related innovations, the company has recently introduced important changes such as the consolidation of their R\&D department and the introduction of more autonomous and multidisciplinary working teams (e.g. the entire process of launching a new product is managed by a single team). The company has a well-planned strategy for innovation as indicated by the existence of the R\&D department (with a permanent staff of five people) and also by its active external links for innovation. In particular they collaborate with universities and technological centres as well as with other companies from similar, but not the same, industry. They do not collaborate with other firms in their market sector in order to avoid knowledge-leaks to potential competitors.

The most significant feature of the company's innovation strategy, however, is that it is strongly determined by the exclusive agreement it has with the large retailer for whom they produce products for the Spanish market. As put by the person interviewed: "Any requirement coming from our partner must be immediately satisfied, we have to sort it out as best we can. At the same time, any new product we develop (even for our own brand) is quickly adopted by the retailer. That is the way it is". Besides this, both formal and informal contacts with the retailer are considered as very important channels to incorporate knowledge into the firm, making the relationship an even more dependent one for the processing company. This finding is in line with the arguments defended by Burch \& Lawrence (2005) regarding the role of food firms as flexible and innovative manufacturers subject to 
retailers' needs and requirements. We could, therefore, affirm that, from the innovation viewpoint also, it is becoming a "retailer dominated" firm.

\section{Company C. Delicatessen firm: territory orientated innovation}

Firm C, the "delicatessen" firm, focussed their innovative activities mainly on the areas of product, market and organization. They did not introduce significant changes to their processes because they deliberately went for artisanal canning as a means of adding value to their product. The previous indicates that the alternative food paradigm, which is based on the close connection there is between quality, territory and nature, is not subject to some technological changes and maintaining (or recovering) traditional knowledge, in line with what has been pointed out by Morgan and Murdoch (2000), is a necessary strategy in itself. Nevertheless, this is not an indication that the company has not been innovative. In fact, the company has carried out product innovation, essentially in order to test or develop new recipes for their canned fish products. On many occasions, this is done by means of hiring professional cooks which, apart from being a new channel to incorporate knowledge, constitutes a market strategy since restaurants are one of their main clients. At the same time, attending fairs and exhibitions, as well as their formal and informal contact with clients, are an important resource for knowing the latest advances in their specialized market. With regards to marketing, they care a lot about the external presentation of their brands and for this reason use attractive designs. Moreover, they have been awarded the regional "pescaderias" certificate that guarantees that the products come from the Galician estuaries and have been fished using artisanal methods. Finally, with regards to organization, the company has recently adopted a more professionalized working structure in which the "quality department" has become more relevant to the company.

Therefore, we can affirm that although this company does not have a planned strategy for innovation, as it does not undertake internal R\&D and neither does it formally cooperate with external agents or institutions in order to innovate, it does not mean that the firm is not innovative. They have been considerably active in everything related to product innovation, incorporating knowledge from professional cooks and also in the promotion of their links with the local territory and its traditions, as a sign of quality. In other fields, such as process innovation, we have seen how not being innovative is a planned decision to maintain traditional and artisanal production methods.

Company D. Ecological firm: innovation orientated by nature 
Finally, the "ecological" firm has a similar innovative profile to the previous one. The launch of their line of ecological products in 2005 has meant an entire change to the company's production system. Innovations have had to be made with particular regard to the provision of new inputs (raw fish, oil, vegetables, etc.) that must adapt to ecological standards and not so much to the canning process itself, since this has not changed significantly. The introduction of ecological products has also been an important product innovation which has been accompanied by other small improvements to product recipes and also to its external presentation (canning and packing). With regards to organization and market-related innovations, the company has put significant effort into the achievement of ecological certification and recognition from important stakeholders within the environmental movement. The company was one of the first in the industry to obtain the acknowledgment of WWFAdena, the well-known environmentalist organization. Recently they have been awarded the official ecological certificate of the Galician government (CRAEGA) as well as the regional "pescaderias" certificate, which, as said before, guarantees that the products originate from the Galician estuaries.

As with the case of the multinational firm, client demands are a major motivation to innovate for this company since they work with a specialized ecological distributor in Germany that partially determines their innovative activity, as well as in terms of product differentiation. The entrance into this specific market segment affects the innovation strategy of the firm, since they need to be in close contact with clients and to attend specialized fairs, in order to make sure that they know about the latest innovations of the sector and to (try) to incorporate them into the firm. They do not give too much importance at all to other factors, such as cost-saving or optimizing processes, since they are not large-scale producers.

Table 2. Innovative strategies of canned fish firms

\begin{tabular}{|c|c|c|c|c|}
\hline & $\begin{array}{l}\text { Innovation } \\
\text { strategy }\end{array}$ & Innovation fields & $\begin{array}{l}\text { Knowledge } \\
\text { and innovation } \\
\text { channels }\end{array}$ & $\begin{array}{l}\text { Reasons to } \\
\text { innovate }\end{array}$ \\
\hline $\begin{array}{l}\text { FIRM } \\
\text { A (Traditional) }\end{array}$ & $\begin{array}{l}\text { Conservative } \\
\text { and provider- } \\
\text { dominated }\end{array}$ & $\begin{array}{l}\text { Only minor process } \\
\text { - innovations }\end{array}$ & Providers & $\begin{array}{l}\text { Only process } \\
\text { optimization } \\
\text { and regulations } \\
\text { fulfillment }\end{array}$ \\
\hline $\begin{array}{l}\text { FIRM B } \\
\text { (Multinational) }\end{array}$ & $\begin{array}{l}\text { Active in all } \\
\text { fields and } \\
\text { large retailer- } \\
\text { dominated }\end{array}$ & $\begin{array}{l}\text { All fields. } \\
\text { Systematized } \\
\text { - innovation }\end{array}$ & $\begin{array}{l}\text { Systematized } \\
\text { R\&D strategy, } \\
\text { formal and } \\
\text { informal contacts } \\
\text { with retailer and } \\
\text { with providers }\end{array}$ & $\begin{array}{l}\text { Diverse, to } \\
\text { attend retailers } \\
\text { demand. Process } \\
\text { optimization and } \\
\text { cost savings }\end{array}$ \\
\hline
\end{tabular}




\begin{tabular}{|c|c|c|c|c|}
\hline & $\begin{array}{l}\text { Innovation } \\
\text { strategy }\end{array}$ & Innovation fields & $\begin{array}{l}\text { Knowledge } \\
\text { and innovation } \\
\text { channels }\end{array}$ & $\begin{array}{l}\text { Reasons to } \\
\text { innovate }\end{array}$ \\
\hline $\begin{array}{l}\text { FIRM C } \\
\text { (Delicatessen) }\end{array}$ & $\begin{array}{l}\text { Territory- } \\
\text { orientated }\end{array}$ & $\begin{array}{l}\text { Mainly marketing } \\
\text { and product } \\
\text { innovations }\end{array}$ & $\begin{array}{l}\text { Artisan } \\
\text { knowledge, } \\
\text { contacts with } \\
\text { clients and } \\
\text { attendance to } \\
\text { fairs }\end{array}$ & $\begin{array}{l}\text { Mainly product } \\
\text { differentiation } \\
\text { and attendance to } \\
\text { client demands }\end{array}$ \\
\hline $\begin{array}{l}\text { FIRM D } \\
\text { (Ecological) }\end{array}$ & $\begin{array}{l}\text { Ecological- } \\
\text { orientated }\end{array}$ & $\begin{array}{l}\text { Mainly } \\
\text { organizational and } \\
\text { commercialization } \\
\text { innovations }\end{array}$ & $\begin{array}{l}\text { Ecological norms, } \\
\text { formal contacts } \\
\text { with clients } \\
\text { (ecological line) } \\
\text { and attendance } \\
\text { to fairs }\end{array}$ & $\begin{array}{l}\text { Adaption to } \\
\text { ecological } \\
\text { production and } \\
\text { attendance to } \\
\text { client demands }\end{array}$ \\
\hline
\end{tabular}

\section{CONCLUSIONS}

In this paper, we have explored the competitive and innovation patterns of the canned fish industry in Galicia (Spain). We have seen how the general and global dynamics of the food value chain, as first described by Malassis (1977) and later elaborated upon by Wilkinson (2002), Morgan et al. (2008) and others, have determined the evolution of this industry. In this sense, the increasingly global nature of food production as well as the rising power of large retailers along the value chain, which can be understood as the main features of the dominant paradigm of food production, have acted as the main source of pressure for change in this industry. In a way, changes in the canned fish industry value chain act both as a context of the innovativeness of the Galician industry and also as a trigger for their innovations. Some (few) companies opted to follow the conventional paradigm, becoming large multinational companies, delocalizing part of their activities and signing exclusive agreements with big retailers in order to produce under their supermarket brands. Other firms did not have the option, or did not aim, to follow this path and instead took an alternative route. While some continue to produce within the same paradigm as they always have, others - in order to avoid the dangers of a conservative strategy - have specialized in narrow market niches basing their competitive strategy on quality and differentiation. This strategy, as pointed out by the literature and as observed in our case studies, relies upon a very close relationship between territory and nature.

We have also observed that the above-mentioned competitive strategies have come hand in hand with different approaches towards innovation and the incorporation of knowledge. At least four different innovation patterns 
can be found in the industry. The first pattern is a conservative one, found in most industries, where innovation is seen as a risk and therefore maintaining routines is the chosen option. The second pattern, as followed in our case study by the multinational firm, can be defined as "large retailer-dominated" as the exclusive agreement between the producer and the retailer increasingly determines all the innovation activities of the producer. The third pattern we have defined as "territory-orientated," since product innovation and the incorporation of quality distinctions based on the territory characteristics are the main innovation drivers. We have even seen how "not innovating" in fields like processing is sometimes a deliberate choice in order to emphasize the artisanal character of production. Nevertheless, in other fields, new knowledge is needed as demonstrated by the close connection with professional cooks in order to test and develop new recipes for canned fish products. Finally, we have an "ecological or nature-orientated" innovation strategy that has been followed by some companies where innovation largely focusses on meeting ecological normative requirements and, in similarity with the retailer-dominated strategy, the demands of ecological product distributors.

All in all, our paper is evidence of how industries' trajectories are influenced by changes in global value chains which act as both the context and the trigger for industry innovations. As suggested by the Evolutionary literature, firms confront their need for adaptation by following diverse, competitive strategies that, at the same time, require different innovative and knowledge acquisition strategies.

\section{Acknowledgments}

The author has received support for this paper from the project EURIPER (EU Regional and Innovation Policies and Peripheral Regions), funded by the European Commission under the Jean Monnet Projects Action of the Erasmus+ Programme (Project Reference: 587410-EPP-1-2017-1-ES-EPPJMO-PROJECT).

\section{References}

ANFACO. (2013). Industria Conservera. Vigo: ANFACO.

ARDAN. (2011). ARDAN Galicia 2011. Vigo: Consorcio Zona Franca.

Burch, D., \& Lawrence, G. A. (2005). Supermarket own brands, supply chains and the transformation of the agri-food system. International Journal of Sociology of Agriculture and Food, 13(1), 1-18.

Carmona, X. (1994). Recursos, organización y tecnología en elcrecimiento de la industria española de conservas de pescado. In J. Nadal \& J. Catalan, La cara oculta de laindustrialización española: la modernización de los sectores no líderes (siglos XIX y XX). Barcelona: Alianza Editorial. 
Carmona, X., \& Fernandez, A. (2001). Demografía y estructura empresarial en la industria gallega de conservas depescado del siglo XX. VII Congreso de la Asociación deHistoria Económica. Zaragoza.

Cohen, M. D., Burkhart, R., Dosi, G., Egidi, M., Marengo, L., Warglien, M., \& Winter, S. (1996). Routines and other recurring action patterns of organisations: Contemporary research issues. Industrial and Corporate Change, 5(3), 653-698.

Dosi, G. (1988). The nature of innovative process. In G. Silverberg \& L. Soete, Technical Change and Economic Theory. London: Pinter.

Freeman, C. (1982). The Economics of Industrial Innovation. London: Frances Pinter.

Grabher, G. (1993). The weakness of strong ties: The lock-in of regional development in Ruhr area. In G. Grabher (Ed.), The Embedded Firm: On the Socioeconomics of Industrial Networks (pp. 255-277). New York: Routledge.

Hayter, R., \& Patchell, J. (2011). Economic Geography: An Institutional Approach. OUP Catalogue.

Malassis, L. (1977). Économie agro-alimentaire. Économie Rurale, 122, 68-72.

Martin, R. (1999). The new 'geographical turn' in economics: Some criticalreflections. Cambridge Journal of Economics, 23, 63-91.

Morgan, K., \& Murdoch, J. (2000). Organic vs. conventional agriculture: Knowledge, power and innovation in the food chain. Geoforum, 31(2), 159-173.

Morgan, K., Marsden, T., \& Murdoch, J. (2008). Worlds of Food: Place, Power, and Provenance in the Food Chain. Oxford: Oxford University Press on Demand.

Nelson, R. (1994). The co-evolution of technology, industrial structure, andsupporting institutions. Industrial and Corporate Change, 3(1), 47-63.

Nelson, R., \& Winter, R. (1982). An Evolutionary Theory of Economic Change (Vol. 3). Cambridge: Harvard University Press.

Pavitt, K. (1984). Sectoral patterns of technical change: Towards a taxonomy and a theory. Research Policy, 13(6), 343-373.

Schamp, E. (2005). Decline of the district, renewal of firms: An evolutionary approach to footwear production in the Pirmasens area, Germany. Environment and Planning, 37(4), 617-634.

Scott, A. (1988). New Industrial Spaces: Flexible Production Organisation and Regional Development in North America and Western Europe. London: Pion.

Storper, M. (1997). The Regional World: Territorial Development in a Global Economy. New York: Guilford Press.

Wilkinson, J. (2002). The final foods industry and the changing face of the global agro-food system. Sociologia Ruralis, 42(4), 329-346. 


\begin{abstract}
Abstrakt
W artykule dokonano analizy konkurencyjnych i innowacyjnych modeli biznesowych, zidentyfikowanych $w$ przemyśle konserw rybnych w ostatnim czasie. Nasze badanie opieramy na czterech analizach przypadków z branży w regionie Galicja w Hiszpanii, w którym zlokalizowano największq część europejskiego sektora konserw rybnych. W branży wyróżnić można co najmniej cztery różne modele innowacji. Pierwszy wzorzec można nazwać konserwatywnym. Innowacyjność jest postrzegana jako ryzyko, dlatego też wybranq opcjq jest utrzymanie aktualnych procesów. Drugi wzorzec określono jako „duży-zdominowany przez detalistów”, wybierany przez firmy, które podpisały wyłączne umowy z dużymi detalistami, którzy w dużym stopniu narzucajq określone działania innowacyjne. Trzecia strategia, którq została zdefiniowana jako "zorientowana terytorialnie", gdyż głównym motorem innowacji (głównie produktowych) sq czynniki zwiq̨zane z lokalizacjq. Ostatniq z wyróżnionych strategii innowacyjnych nazwano „ekologicznq lub zorientowanq na naturę”, w której spełnienie ekologicznych wymagań normatywnych jest głównq siłq napędowq innowacji.

Słowa kluczowe: konserwy rybne, innowacje, trajektorie, przemysł spożywczy, łańcuch wartości, detaliści, marki własne, terytorium, produkty ekologiczne.
\end{abstract}

\title{
Biographical note
}

Manuel González López is a Ph.D. lecturer and researcher at the Department of Applied Economics, University of Santiago de Compostela, Galicia (Spain). He holds an MSc and MPhil in Social Sciences from the University of Manchester (UK) and he has been a visiting researcher at several European universities. His main fields of research are Economics of Innovation, Regional Economics in the European Union and innovation dynamics in the Food Sector. He has published numerous papers in several international journals. He currently coordinates the project EURIPER (EU Regional and Innovation Policies and Peripheral Regions), funded by the European Commission under the Jean Monnet Projects Action of the Erasmus+ Programme. 